\title{
Effect of Staphylococcus aureus Infection on Biochemical and Antioxidant Activities of Fifth Instar Silkworm Larvae (Bombyx mori L.)
}

Harinatha Reddy A* and Venkatappa B

Department of Microbiology, Sri Krishnadevaraya University, Anantapur-515003, Andhra Pradesh, India

*Corresponding author: Harinatha Reddy A, Department of Microbiology, Sri Krishnadevaraya University, Anantapur-515003, A.P, India, Tel: +919000616285; E-mail: biohari14@gmail.com

Received date: August 09, 2016; Accepted date: August 29, 2016; Published date: August 31, 2016

Copyright: ( 2016 Reddy $\mathrm{AH}$, et al. This is an open-access article distributed under the terms of the Creative Commons Attribution License, which permits unrestricted use, distribution, and reproduction in any medium, provided the original author and source are credited.

\begin{abstract}
In the present study silkworm used as a model animal for evaluating the pathogenicity of Staphylococcus aureus. The fifth instar silkworm larvae was used and infected by intrahaemocoelic injection of bacterial sample. The haemolymph was collected from the infected and control group larvae at 6, 12, 18 and 24 hours of post infection and stored at $-4^{\circ} \mathrm{C}$ in eppendorf tubes to use. Lipid peroxidation, phenol oxidase and acid phosphatase activity were estimated in the haemolymph of control and infected group. This indicated that there was a gradual increase in lipid peroxidation, phenol oxidase and acid phosphatase activities in infected group when compared with control group. The antioxidant enzyme activities were estimated in the haemolymph of control and infected group. We found that the antioxidant enzyme activities were decreased after 24 hours of infection with $S$. aureus. The silk glands were removed and the wet weight was measured, the wet weight of the silk glands was decreased on the 24 hours of infection when compared with control group.
\end{abstract}

Keywords: Acid phosphatase; Haemolymph; Lipid peroxidation; Phenol oxidase; Silk gland

\section{Introduction}

Silkworm is a domesticated and economically important insect, being a primary producer of silk. The silkworm larval infection model has been proposed as a system in which to evaluate novel antimicrobial agents [1]. Microorganisms that are pathogenic to humans, such as Staphylococcus aureus, Pseudomonas aeruginosa and Candida albicans, have lethal effects in silkworms when injected into the haemolymph [2-5]. There are several advantages to using silkworms as an infection model, such as low cost, the absence of ethical problems that are associate with the use of mammals and a body size large enough to handle while injecting sample solution into the haemolymph [3].

Staphylococcus is a genus of Gram positive, non-spore forming cocci found in the human respiratory tract and on the skin. $S$. aureus can cause serious infections such as skin, bloodstream infections (Bacteremia), pneumonia, bone and joint infections. Methicillin-resistant Staphylococcus aureus (MRSA) is a major cause of hospital acquired infections that are becoming increasingly difficult to combat because of emerging resistance to all current antibiotic classes [6]. These strains appear to contain particular factors or genetic backgrounds that enhance their virulence [7]. $S$. aureus produces a wide variety of exotoxins that contribute to its ability to colonize and cause disease in mammalian hosts. This includes four hemolysins (alpha, beta, gamma, and delta), nucleases, proteases, lipases, hyaluronidase and collagenase. The main function of these exotoxins to convert local host tissues into nutrients required for bacterial growth [8]. Alpha-toxin, the major cytotoxic agent elaborated by $S$. aureus, was the first bacterial exotoxin to be identified as a pore former [9]. Toxic shock syndrome toxin (TSST) is the super antigen of the $S$. aureus, it causes toxic shock syndrome (TSS) by stimulating release of IL-1, IL-2, TNF- $\alpha$ and other cytokines [10].

$S$. aureus infection caused a marked decrease in plasma antioxidant defence systems illustrated by significant reductions in plasma paraoxonase activity, thiol concentrations in infected rabbits [11]. $S$. aureus infection causes decrease in superoxide dismutase activity, glutathione peroxidase activity, catalase activity and accumulation of lipid peroxidative products (MDA) in infected animal models by reduction in plasma paraoxonase activity, thiol concentrations. Formation of reactive oxygen species (ROS) and lipid peroxidation is a common phenomenon during infectious diseases. These free radicals causes' tissue injury and cell death, lipids of cells membranes and organelles are frequently damaged, resulting in lipid peroxidation. Staphylococcal infections are typically associated with death of tissue and evidence suggests intracellular bacteria are capable of inducing apoptosis [12]. S. aureus induce apoptosis has been reported in epithelial cells [13-15], keratinocytes [16], endothelial cells [17] and osteoblasts [18].

\section{Materials and Methods}

\section{Rearing of Bombyx mori larvae}

Fifth instar day sixth larvae of CSR-4 strain was reared in the laboratory by the improved method of rearing technique [19]. The silkworms are maintained on mulberry leaves at a temperature of $27^{\circ} \mathrm{C}$ and relative humidity of $75 \%$. The life span of the silkworm under these conditions was 30-32 days.

\section{Preparation of bacterial sample}

Mannitol salt agar (MSA) medium was prepared a loopful sample of S. aureus bacterial sample was streaked on MSA and incubated at $37^{\circ} \mathrm{C}$ 
for 24 hours. After incubation $S$. aureus formed golden yellow color colonies on MSA medium.

\section{Inoculation of bacteria in Luria broth (LB)}

A loopful of bacteria was taken with the help of a loop and streaked onto Luria broth (LB $1000 \mathrm{ml}$ ) and incubated at $37^{\circ} \mathrm{C}$ overnight. The inoculated LB sample was centrifuged for $15 \mathrm{~min}$ at $4000 \mathrm{rpm}$. By discarding the supernatant, pellet sediment at the bottom of the tube was dissolved in $100 \mathrm{ml}$ of distilled water. The number of bacteria cells in the bacterial culture suspension was calculated by colony-forming unit (CFU).

\section{Infection of silkworm larvae with bacterial strain}

Fifth instar silkworm larvae were divided in to two groups, each group consisting of 20-30 larvae. One group was infected with the bacterium $\left(3 \times 10^{5} \mathrm{cfu} / \mathrm{ml}\right.$ to $\left.1 \times 10^{8} \mathrm{cfu} / \mathrm{ml}\right)$ by intrahaemocoelic injection of bacterial sample. A similar number of larvae were injected with distilled water and considered as a control. Both control and infected larvae were reared under room temperature. The time of infection was recorded and the haemolymph was collected from the infected and control group larvae at 6, 12, 18 and 24 hours, post infection and stored at $-4^{\circ} \mathrm{C}$ in eppendorf tubes to use.

\section{Lipid peroxidation assay}

To $0.5 \mathrm{ml}$ of the homogenate (haemolymph), $0.5 \mathrm{ml}$ of buffer, $2 \mathrm{ml}$ of TCA (Trichloroacetic acid) were added followed by $4 \mathrm{ml}$ of TBA (Thiobarbituric acid). The contents were heated in a water-bath at $100^{\circ} \mathrm{C}$ for $20 \mathrm{~min}$. After cooling and centrifugation, the absorbance of the supernatant was read at $535 \mathrm{~nm}$. A reagent blank was prepared using water instead of homogenate. The extent of lipid peroxidation was expressed as $\mathrm{n}$ mole of MDA formed/mg protein using a molar extinction coefficient for MDA of $1.56 \times 10^{5} \mathrm{M}^{-1} \mathrm{~cm}$.

\section{Phenol oxidase assay}

The phenoloxidase activity was determined by the method of Horowitz and Shen [20]. The reaction mixture consisted of $1 \mathrm{ml}$ of 0.02 $\mathrm{M}$, 4-di hydroxyphenylalanine (DOPA), $3.9 \mathrm{ml}$ of $0.1 \mathrm{M}$ phosphate buffer, pH 6.0 and $0.1 \mathrm{ml}$ of enzyme solution. After incubation at $30^{\circ} \mathrm{C}$ for 5 minutes the color intensity of dopachrome was measured at 490 $\mathrm{nm}$.

\section{Acid phosphatase assay}

Acid phosphatase activities were determined by the liberation of $\mathrm{p}$ nitrophenol from the appropriate p-nitrophenyl substrate according to the method reported by De Couet and Blest [21]. The assay mixture contained $10 \mu \mathrm{l}$ of tissue homogenate and $200 \mu \mathrm{l}$ of substrate solution ( $2 \mathrm{mg} / \mathrm{ml} \mathrm{p}$-nitrophenyl phosphate, $1 \mathrm{mg} / \mathrm{ml}$ bovine serum albumin in homogenization buffer with $0.1 \mathrm{~mol} / \mathrm{l}$ TRIS maleate at $\mathrm{pH} 5.2$ ). The enzyme reaction was carried out at $21^{\circ} \mathrm{C}$ and samples arrested at 15 min intervals by addition of $50 \mu \mathrm{l} 4 \mathrm{~N} \mathrm{NaOH}$ over 1 hour period. The reaction mixtures were then centrifuged at $1000 \mathrm{~g}$ for $10 \mathrm{~min}$ at room temperature and remove precipitate. Blanks were prepared by addition of $\mathrm{NaOH}$ prior to enzyme solution. Color development was determined at $405 \mathrm{~nm}$ using spectrophotometer. Readings were compared to a standard curve prepared with p-nitrophenol, the activity of enzyme was represented by $\mu \mathrm{mol} / \mathrm{min} / \mathrm{mg}$.

\section{Estimation of protein in the haemolymph}

The total protein content was determined with Folin Ciocalteau's reagent according to the Lowry et al. [22]. Aliquot of test sample was made up to $1.0 \mathrm{ml}$ with distilled water and $5.0 \mathrm{ml}$ of alkaline solution was added, mixed thoroughly and allowed to stand at room temperature for $10 \mathrm{~min}$. Then $0.5 \mathrm{ml}$ of Folin-Ciocalteau's reagent was added rapidly with immediate mixing and the intensity of the colour developed was read at $750 \mathrm{~nm}$ after $30 \mathrm{~min}$. Values are calculated from the standard graph.

\section{Glutathione peroxidase (GPx) assay}

The assay mixture consisted of $0.02 \mathrm{ml}$ enzyme source, $1.78 \mathrm{ml}$ buffer, $0.06 \mathrm{ml} \mathrm{GSH}, 0.02$ glutathione reductase and $0.06 \mathrm{ml} \mathrm{NADPH}$. The reaction was initiated by the addition of $0.06 \mathrm{ml}$ of $\mathrm{H}_{2} \mathrm{O}_{2}$. The change in absorbance was recorded at $1 \mathrm{~min}$ intervals at $340 \mathrm{~nm}$ and the specific activity was calculated using extinction co-efficient of 6.22 $\mathrm{cm}^{-2} / \mu \mathrm{mol}$ for NADPH. The activity was expressed as $\mathrm{n}$ mole NADPH oxidized $/ \mathrm{min} / \mathrm{mg}$ protein.

\section{Catalase assay}

Catalase catalyzes the breakdown of $\mathrm{H}_{2} \mathrm{O}_{2}$ to $\mathrm{H}_{2} \mathrm{O}$ and $\mathrm{O}_{2}$ the rate of decomposition of $\mathrm{H}_{2} \mathrm{O}_{2}$ measured spectrophotometrically at $240 \mathrm{~nm}$ as outlined by Beers and Sizer [23]. The assay system contained $1.98 \mathrm{ml}$ of Phosphate buffer, $0.02 \mathrm{ml}$ of the enzyme source and $1.0 \mathrm{ml}$ of $\mathrm{H}_{2} \mathrm{O}_{2}$. The change in absorbance was monitored at $240 \mathrm{~nm}$ and specific activity was calculated using a molar absorbance index for $\mathrm{H}_{2} \mathrm{O}_{2}$ of 43.6. The specific activity was expressed as moles of $\mathrm{H}_{2} \mathrm{O}_{2}$ decomposed $/ \mathrm{min} / \mathrm{mg}$ protein.

\section{Superoxide dismutase (SOD) assay}

Superoxide dismutase activity was measured based on the ability of the enzyme to inhibit the autooxidation of pyrogallol according to the method of Marklund and Marklund [24]. The assay system contained $2.1 \mathrm{ml}$ of phosphate buffer, 0.02 of enzyme source and $0.86 \mathrm{ml}$ of distilled $\mathrm{H}_{2} \mathrm{O}$. The reaction was initiated with the addition of $0.02 \mathrm{ml}$ of pyrogallol and change in absorbance was monitored at $420 \mathrm{~nm}$. The percent inhibition was calculated on the basis of blank assay system. One unit of SOD was defined as the amount of enzyme required to inhibit the autooxidation of pyrogallol. The specific activity was expressed as unit $/ \mathrm{min} / \mathrm{mg}$ protein.

\section{Measurement of silk gland weight}

After anesthesia, the silkworms were placed on a cork board, and the head and tail were pinned to it. A small cut was made in the tail, from which the abdomen was opened longitudinally by running ophthalmological scissors toward the head, and the silk gland, midgut, located in the middle of the abdomen, were removed. The wet weight of the silk gland was measured using a balance just after removal [25].

\section{Statistical analysis}

All the results are expressed as means \pm SE. Statistical analysis of the data was performed by Student's t-test and $\mathrm{P}$ value $<0.05$ was considered statistically significant. 
Citation: Reddy HA, Venkatappa B (2016) Effect of Staphylococcus aureus Infection on Biochemical and Antioxidant Activities of Fifth Instar Silkworm Larvae (Bombyx mori L.). J Bacteriol Parasitol 7: 286. doi:10.4172/2155-9597.1000286

Page 3 of 7

\section{Result and Discussion}

\section{Lipid peroxidation (LPO) assay}

The malondialdehyde (MDA) concentration was increased in the haemolymph of silkworm larvae infected with $S$. aureus when compared with control group. The highest MDA concentration (4.65 $\mathrm{MDA} \mathrm{nmol} / \mathrm{ml}$ ) was reported at 24 hours post infection with bacteria (Figure 1). The MDA concentration was the same as that of the control larvae at 6 hours of infection, later the MDA concentration gradually increased at 12, 18 and 24 hours post infection with bacteria. The results obtained testify that the high level of lipid peroxidation at 24 hours post inoculation may be the result of cells destruction by exo and endotoxins of $S$. aureus. Generally the ROS are formed in small quantities during the metabolism, however, the production of ROS is increased during the infection [26]. The formation of lytic pores in the plasmatic membrane and the disconnection of oxidative phosphorylation processes may result in the overproduction of reactive oxygen species (ROS) causes lipid peroxidation [27].

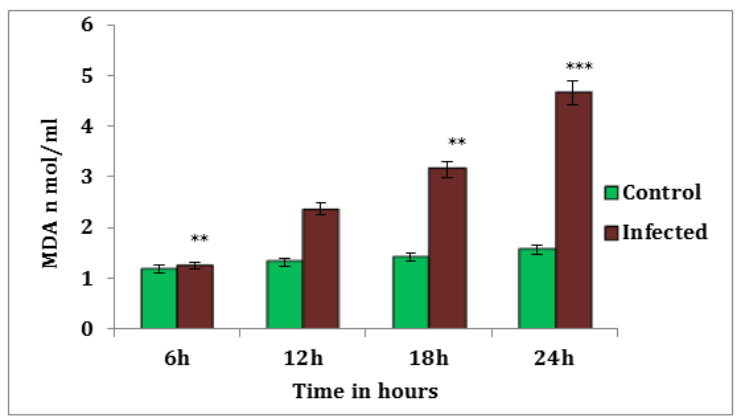

Figure 1: MDA concentration in the haemolymph of control and infected larvae of $B$. mori Values are mean \pm SE from 8 silkworms in each group. Superscripts are significantly different at ${ }^{\star} \mathrm{P} \leq 0.05$, ${ }^{* *} \mathrm{P} \leq 0.01,{ }^{* * *} \mathrm{P} \leq 0.001$.

\section{Phenoloxidase (PO) assay}

The phenol oxidase (PO) activity increased in the infected larvae when compared with control group at 12,18 and 24 hours post infection (Figure 2) which indicates that PO activity was highly active against $S$. aureus. In melanization cascade, $\mathrm{PO}$ is the terminal enzyme, play an important role in defense mechanisms in invertebrates [28]. Phenol oxidase that catalyses the hydroxylation of tyrosine to DOPA (dihydroxylphenyl alanine) and the oxidation of DOPA to dopaquinone, is usually found as pro enzyme in the haemolymph and activated in response to defense reactions [29]. PO is present throughout the body of insects including the open circulatory system of haemolymph and haemocytes activated by the microbial factors. Activated prophenol oxidase (proPO) plays an important role in cuticular melanization of foreign organisms and sclerotization.

\section{Acid phosphatase assay}

The acid phosphatase activity was increased in infected larvae from 18 hours and 24 hours of post infection when compared with control group (Figure 3 ). The major changes were not observed in the acid phosphatase during 6 hours and 12 hours post infection when compared with control group. The gradual increase in the concentration of acid phosphatase correlated with an increase of its activity in the haemolymph of the inoculated larvae as a response to infection with $S$. aureus. Acid phosphatase, used as a marker enzyme for lysosomes and apoptosis, involved in the degradation of insect tissues [30]. Lysosomal participation during the programmed cell death of tissues has been confirmed by the elevated level of the acid phosphatase [31]. Variations in the activity of the acid phosphatase of silkworm were studied in all stages of the life cycle of the Bombyx mori, during spinning stage, a steady increase was recorded in the activity of acid phosphatase [32]. Acid phosphatase may have a role in autophagy and cell turnover as well as defense [33].

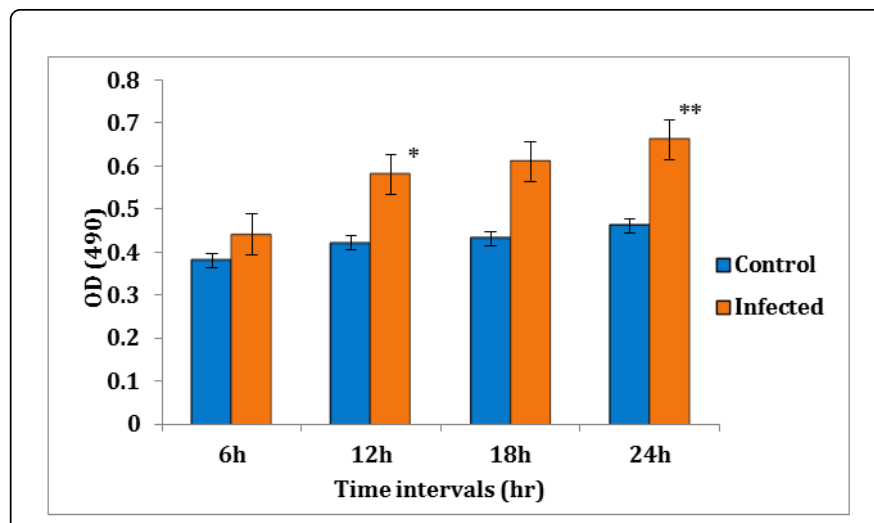

Figure 2: Phenoloxidase activity in the haemolymph of control and infected larvae of $B$. mori Values are mean \pm SE from 8 silkworms in each group. Superscripts are significantly different at ${ }^{\star} \mathrm{P} \leq 0.05$, ${ }^{* *} \mathrm{P} \leq 0.01$.

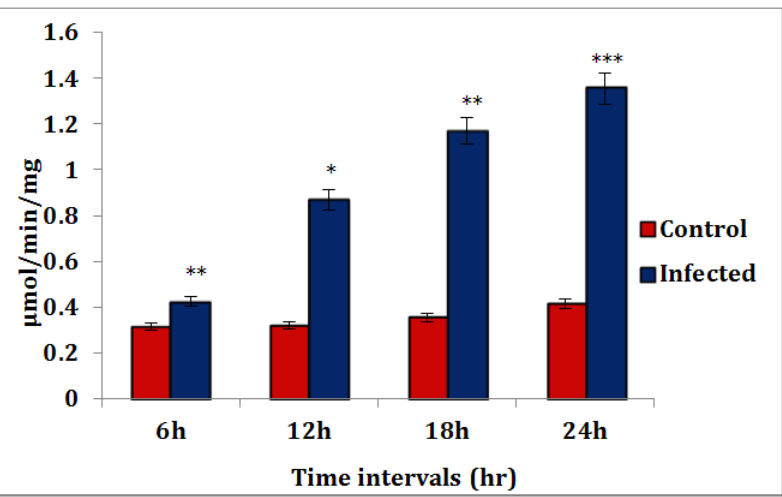

Figure 3: Acid phosphatase activity in the haemolymph of control and infected larvae of $B$. mori Values are mean \pm SE from 8 silkworms in each group. Superscripts are significantly different at ${ }^{*} \mathrm{P} \leq 0.05,{ }^{* *} \mathrm{P} \leq 0.01,{ }^{*} \mathrm{P} \leq 0.01$.

\section{Estimation of protein in the haemolymph}

Increased trend of protein concentration was recorded in infected group from 12, 18 and 24 hours post infection with $S$. aureus (Figure 4). The major changes were not observed at 6 hours post infection when compared with control group. The haemolymph composition of 
Citation: Reddy HA, Venkatappa B (2016) Effect of Staphylococcus aureus Infection on Biochemical and Antioxidant Activities of Fifth Instar

insects reflects the nature and degree of metabolism of the tissues, any changes in the protein concentration of the haemolymph may show the level of modification in the organism [34]. During infection profound biochemical changes occur in the haemolymph, particularly in the concentration of proteins. The immune response induced against $S$. aureus in response to infection is the synthesis of antimicrobial peptides in silkworm haemolymph may be the reason for the elevation of protein content during bacterial infection.

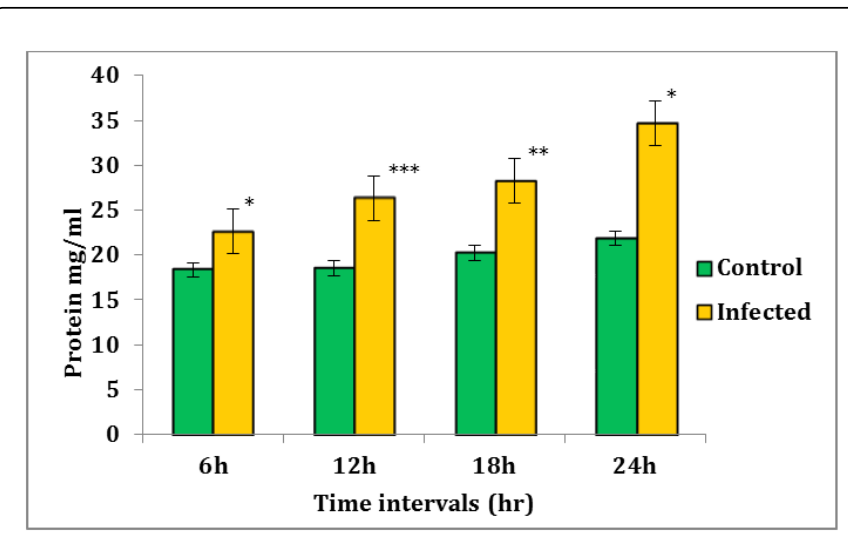

Figure 4: Protein concentration in the haemolymph of control and infected larvae of $B$. mori Values are mean \pm SE from 8 silkworms in each group. Superscripts are significantly different at ${ }^{\star} \mathrm{P} \leq 0.05$, ${ }^{*} \mathrm{P} \leq 0.01,{ }^{* *} \mathrm{P} \leq 0.01$.

\section{Glutathione peroxidase (GPx) assay}

Glutathione peroxidase (GPx) activity decreased gradually in infected group when compared with control group. The lowest GPx activity $(0.121 \mathrm{nmol} \mathrm{NADPH} / \mathrm{min} / \mathrm{mg}$ protein) was recorded at 24 hours post infection with bacteria (Figure 5). GPx is the general name of an enzyme family with peroxidase activity whose main biological role is to protect the organism from oxidative damage. The biochemical function of GPx is to reduce lipid hydroperoxides to their corresponding alcohols and to reduce free hydrogen peroxide to water. Glutathione peroxidase activity inhibited loss of polyunsaturated fatty acids from microsomes and mitochondria when they were exposed to peroxidizing conditions [35]. Alterations of these enzyme levels are associated with diverse cancer types, including skin, kidney, intestine and breast cancer [36].

\section{Catalase (CAT) assay}

Cytosolic enzyme catalase is a component of antioxidant defense system that reduces hydrogen peroxide $\left(\mathrm{H}_{2} \mathrm{O}_{2}\right)$ to water and protect the cell from oxidative damage [37]. A significant reduction in enzyme activity was noticed in the infected larvae when compared to control group after 24 hours of infection with pathogenic bacteria (Figure 6). The peroxisomal catalases might be crucial factors for adaptation to oxidative stress generated during bacterial growth [38,39]. The significant reduction of the enzyme activity was observed in infected larvae which may be due to metabolic adjustments as the part of the defense system of the host as a consequence of bacterial invasion.

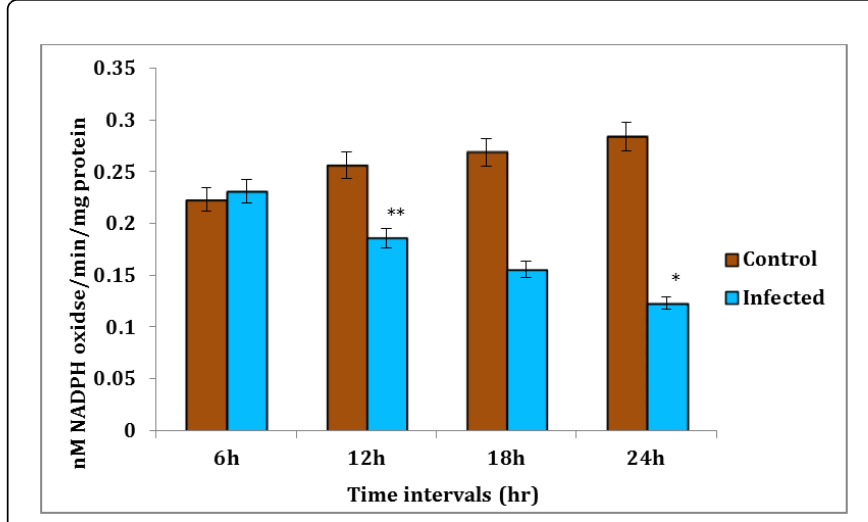

Figure 5: Glutathione peroxidase activity in the haemolymph of control and infected larvae of $B$. mori. Values are mean \pm SE from 8 silkworms in each group. Superscripts are significantly different at ${ }^{\star} \mathrm{P} \leq 0.05,{ }^{\star *} \mathrm{P} \leq 0.01$.

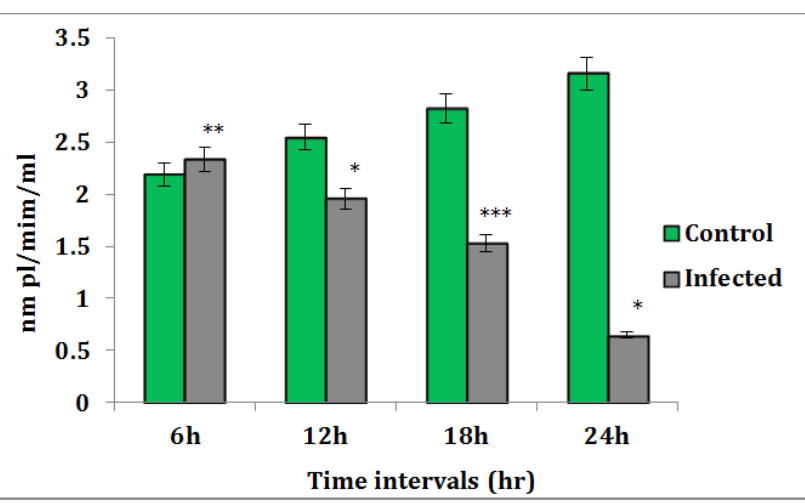

Figure 6: Catalase activity in the haemolymph of control and infected larvae of B. mori. Values are mean \pm SE from 8 silkworms in each group. Superscripts are significantly different at ${ }^{\star} \mathrm{P} \leq 0.05$, ${ }^{* *} \mathrm{P} \leq 0.01,{ }^{* *} \mathrm{P} \leq 0.01$.

\section{Superoxide dismutase (SOD) assay}

Superoxide dismutase (SOD) activity increased at 6 hours post infection, during the later hours of infection SOD activity decreased gradually when compared to control group (Figure 7). The highest SOD activity $(0.325 \mathrm{U} / \mathrm{mg}$ protein) was recorded at 6 hours post infection and lowest activity $(0.192 \mathrm{U} / \mathrm{mg}$ protein) at 24 hours post infection with bacteria. Superoxide dismutase (SOD) is an enzyme facilitating the removal of superoxide anions from living organisms, which catalyzes the conversion of the superoxide radicals into molecular $\mathrm{O}_{2}$ and $\mathrm{H}_{2} \mathrm{O}_{2}$ and thus form a crucial part of the cellular antioxidant defense mechanism [40]. SOD activity was decreased in the haemolymph of infected larvae, due to the significant reductions in plasma paraoxonase activity, thiol concentrations in infected larvae. 
Citation: Reddy HA, Venkatappa B (2016) Effect of Staphylococcus aureus Infection on Biochemical and Antioxidant Activities of Fifth Instar Silkworm Larvae (Bombyx mori L.). J Bacteriol Parasitol 7: 286. doi:10.4172/2155-9597.1000286

Page 5 of 7

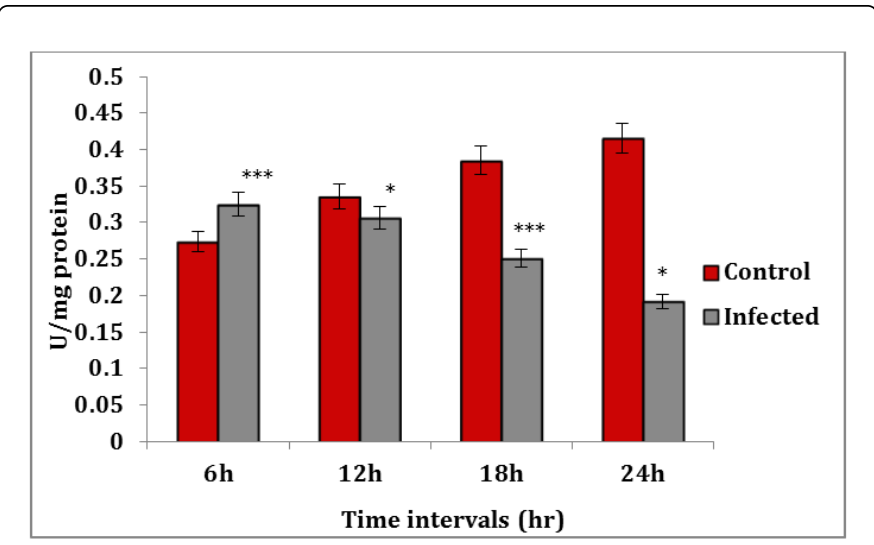

Figure 7: Superoxide dismutase activity in the haemolymph of control and infected larvae of $B$. mori. Values are mean \pm SE from 8 silkworms in each group. Superscripts are significantly different at ${ }^{\star} \mathrm{P} \leq 0.05,{ }^{\star *} \mathrm{P} \leq 0.01,{ }^{* \star} \mathrm{P} \leq 0.01$.

\section{Mortality}

In the developmental life cycle of an insect, considerable variation in the susceptibility has been established. Each stage differs in its susceptibility and degree of resistance. At 6 hours of infection with bacteria only $0 \%$ of mortality was reported, the percentage of mortality was gradually increased at 12,18 and 24 hours of infection with bacteria (Figure 8 ). The percentage of mortality clearly demonstrates an increased susceptibility at 12,18 and 24 hours of infection with bacteria.

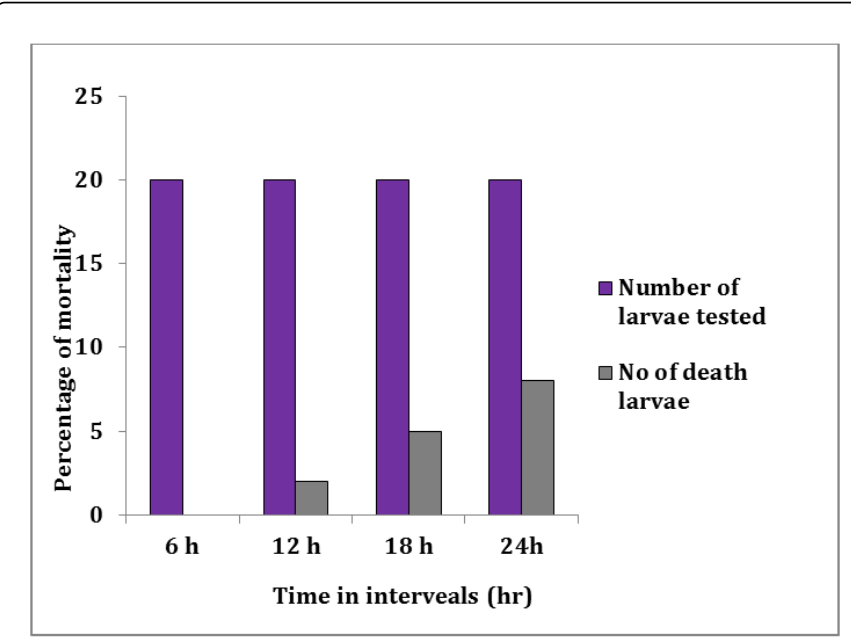

Figure 8: Relationship between $S$. aureus pathogenicity and silkworm larvae.

\section{Measurement of silk gland weight}

The major changes were not observed in the silk glands of infected group when compared with control group. But the weight of the silk glands in infected group was lower when compared with control group (Figure 9). At every hour silkworms were dissected and the silk glands (5 pairs) were collected, the weights of silk glands were recorded in grams. The silk glands do not exhibit any signs and symptoms of bacterial infection (Figure 10).

Silkworm salivary glands are not susceptible to bacterial and viral infections [41]. Silk gland weight and shell weight also significantly declined following infection over uninfected larvae. Silk gland assimilates the mulberry protein in the course of larval development and grows considerable size and weight to provide protein material during the spinning of the cocoon. The process of protein assimilation and growth of silk gland depend mainly on the physiological conditions of the silkworm during larval growth. The decrease in weight of the silk gland was observed in the infected larvae when compared with control group. This suggests that $S$. aureus interferes with the normal physiology of the silkworm and affects the weight of the silk gland possibly by reducing the assimilation of proteins.

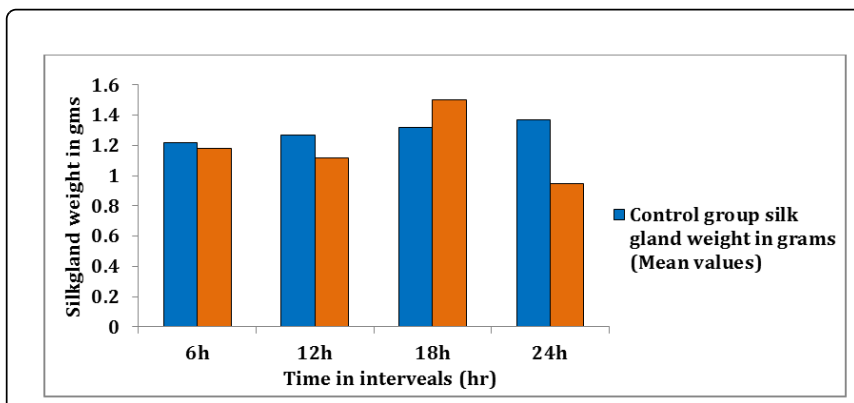

Figure 9: Measurement of silk gland weight of the control and infected larvae (Silk gland weight in grams (Mean values).

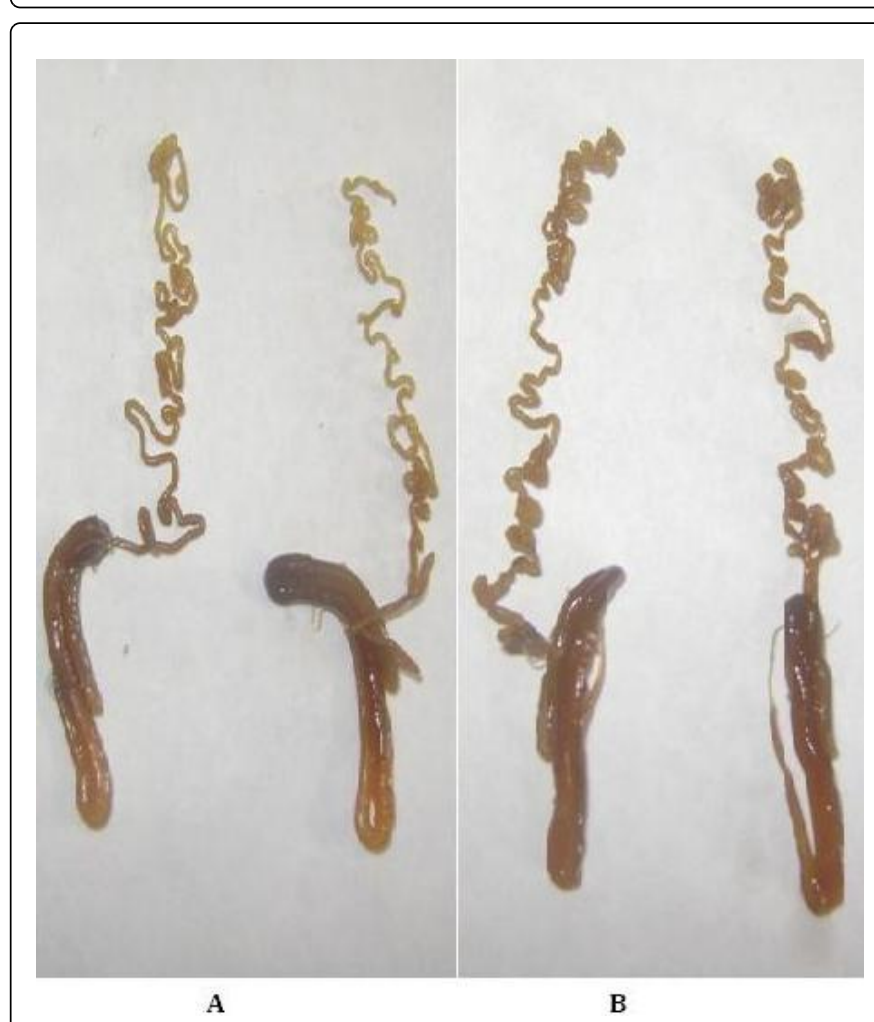

Figure 10: Pair of silk glands from (A). Control and (B). Infected silk worm larvae after $24 \mathrm{~h}$ infection with bacteria. 


\section{Conclusion}

Infection of $S$. aureus causes significant increase in MDA concentration, acid phosphatase and phenoloxidase activity after $24 \mathrm{~h}$ of infection in fifth instar silkworm larvae. Protein concentration in haemolymph markedly increased in infected larvae following appearance of disease symptoms. $S$. aureus has ability to altering antioxidant levels such as superoxide dismutases (SOD), catalase and glutathione levels and cause death of silkworms. The silk glands did not exhibit any signs and symptoms of bacterial infection indicated that silk glands are resistant to $S$. aureus infection. From the above studies it is concluded that silkworms as a good animal model to study pathogenicity of bacteria.

\section{Acknowledgement}

The authors express their sincere thanks to DST INSPIRE Fellowship, New Delhi for financial support to carry out this research work.

\section{References}

1. Fujiyuki T, Imamura K, Hamamoto H, Sekimizu K (2010) Evaluation of therapeutic effects and pharmacokinetics of antibacterial chromogenic agents in a silkworm model of Staphylococcus aureus infection. Drug Discov Ther 4: 349-354.

2. Kaito C, Kurokawa K, Matsumoto Y, Terao Y, Kawabata S, et al. (2005) Silkworm pathogenic bacteria infection model for identification of novel virulence genes. Mol Microbiol 56: 934-944.

3. Kaito C, Sekimizu K (2007) A silkworm model of pathogenic bacterial infection. Drug Discov Ther 1: 89-93.

4. Hamamoto H, Kurokawa K, Kaito C, Kamura K, Manitra Razanajatovo I, et al. (2004) Quantitative evaluation of the therapeutic effects of antibiotics using silkworms infected with human pathogenic microorganisms. Antimicrob Agents Chemother 48: 774-779.

5. Hossain MS, Hamamoto H, Matsumoto Y, Razanajatovo IM, Larranaga J, et al. (2006) Use of silkworm larvae to study pathogenic bacterial toxins. J Biochem 140: 439-444.

6. Enright MC, Robinson DA, Randle G, Feil EJ, Grundmann H, et al. (2002) The evolutionary history of methicillin-resistant Staphylococcus aureus (MRSA). Proc Natl Acad Sci USA 99: 7687-76892.

7. Gordon RJ, Lowy FD (2008) Pathogenesis of methicillin-resistant Staphylococcus aureus infection. Clin Infect Dis 46: S350-S359.

8. Dinges MM, Orwin PM, Schlievert PM (2000) Exotoxins of Staphylococcus aureus. Clin Microbiol Rev 13: 16-34.

9. Bhakdi S, Tranum-Jensen J (1991) Alpha-toxin of Staphylococcus aureus Microbiol Rev 55: 733-751.

10. Otto M (2014) Staphylococcus aureus toxins. Curr Opin Microbio 17 32-37.

11. Vlaykova T, Georgieva TM, Dishlyanova E, Bozakova N, Georgiev P (2013) Effects of acute Staphylococcus aureus infection on paraoxonase activity, thiol concentrations and ferric reducing ability of plasma in rabbits. Revue Méd Vét 164: 125-131.

12. Alexander EH, Rivera FA, Marriott I, Anguita J, Bost KL, et al. (2003) Staphylococcus aureus induced tumor necrosis factor related apoptosis inducing ligand expression mediates apoptosis and caspase- 8 activation in infected osteoblasts. BMC Microbiol 3: 5.

13. Bayles KW, Wesson CA, Liou LE, Fox LK, Bohach GA, et al. (1998) Intracellular Staphylococcus aureus escapes the endosome and induces apoptosis in epithelial cells. Infect Immun 66: 336-342.

14. Kahl BC, Goulian M, Wamel WV, Herrmann M, Simon SM, et al. (2000) Staphylococcus aureus RN6390 replicates and induces apoptosis in a pulmonary epithelial cell line. Infect Immun 68: 5385-5392.
15. Wesson CA, Deringer J, Liou LE, Bayles KW, Bohach GA (2000) Apoptosis induced by Staphylococcus aureus in epithelial cells utilizes a mechanism involving caspases 8 and 3. Infect Immun 68: 2998-3001.

16. Nuzzo I, Sanges MR, Folgore A, Carratelli CR (2000) Apoptosis of human keratinocytes after bacterial invasion. FEMS Immunol Med Microbiol 27: 235-240.

17. Menzies BE, Kourteva I (2000) Staphylococcus aureus a-toxin induces apoptosis in endothelial cells. FEMS Immunol Med Microbiol 29: 39-45.

18. Tucker KA, Reilly SS, Leslie CS, Hudson MC (2000) Intracellular Staphylococcus aureus induces apoptosis in mouse osteoblasts. FEMS Microbiol Lett 186: 151-156.

19. Krishnaswami S (1978) New technology of Silkworm rearing. CSR \&TI, Bulletin Mysore 2: 1-23.

20. Horowitz NH, Shen SC (1952) Neurospora tyrosinase. J Biol Chem 197: 513-520.

21. De Couet HG, Blest AD (1982) The retinal acid phosphatase of a crab, Leptograpsus: Characterization, and relation to the cyclical turnover of photoreceptor membrane. J Comparative Physiol 149: 353-362.

22. Lowry OH, Rosebrough NJ, Farr AL, Randall RJ (1951) Protein measurement with Folin phenol reagent. J Biol Chem 193: 265-275.

23. Beers RJ, Sizer IW (1952) Spectrophotometric method for measuring breakdown of $\mathrm{H}_{2} \mathrm{O}_{2}$ catalase. J Biol Chem 195: 133-140.

24. Marklund S, Marklund G (1974) Involvement of the superoxide anion radical in the autoxidation of pyrogallol and a convenient assay for superoxide dismutase. Eur J Biochem 47: 469-474.

25. Shinohara Y, Ishii N, Takahashi S, Okazaki T (2008) Appearance of apoptotic cells and granular cells in the silkworm midgut lumen during larval-pupal ecdysis. Zoolog Sci 25: 139-145.

26. Knapowski J, Wieczorowska-Tobis K, Witowski J (2002) Pathophysiology of aging. J Physiol Pharmacol 53:135-146.

27. Dubovskiy IM, Martemyanov VV, Vorontsova YL, Rantala MJ, Gryzanova EV, et al. (2008) Effect of bacterial infection on antioxidant activity and lipid peroxidation in the midgut of Galleria mellonella L. larvae (Lepidoptera, Pyralidae). Comp Biochem Physiol C Toxicol Pharmacol 148: $1-5$.

28. Liu H, Jiravanichpaisal P, Cerenius L, Lee BL, Söderhäll I (2007) Phenoloxidase is an important component of defense against Aeromonas hydrophilla infection in a Crustacean Pacifastacus leniusculus. J Biol Chem 282: 33593-33598.

29. Sugumaran M, Duggaraju P, Jayachandran E, Kirk KL (1999) Formation of a new quinone methide intermediate durin the oxidative transformation of 3,4-dihydroxyphenylacetic acids: Implications for eumelanin biosynthesis. Arch Biochem Biophys 371: 98-106.

30. Halaby R, Martinez ML, Lockshin RA, Zakeri Z (2003) 20 Hydroxyecdysone induces apoptosis in the labial gland of Manduca sexta. J Res Lepid 37: 3-10.

31. Sumithra P, Britto CP, Krishnan M (2010) Modes of cell death in the pupal perivisceral fat body tissue of the silkworm Bombyx mori L. Cell Tissue Res 339: 349-358.

32. Sridhara S, Bhat JV (1963) Alkaline and acid phosphatases of the silkworm, Bombyx mori L. J Insect Physiol 9: 693-701.

33. Xia Y, Dean P, Judge AJ, Gillespie JP, Clarkson JM (2000) Acid phosphatases in the haemolymph of the desert locust, Schistocerca gregaria, infected with the entomopathogenic fungus Metarhizium anisopliae. J Insect Physiol 46: 1249-1257.

34. Mahesha HB, Thejaswini PH, Honnaiah S (2000) Haemolymph proteins of $\mathrm{F} 1$ progeny raised from ethyl methanesulfonate treated silkworm Bombyx mori L. Indian J Seric 39: 139-44.

35. McCray PB, Gibson DD, Fong KL, Hornbrook KR (1976) Effect of glutathione peroxidase activity on lipid peroxidation in biological membranes. Biochim Biophys Acta 431: 459-468.

36. Townsend DM, Tew KD (2003) The role of glutathione $S$ transferase in anti-cancer drug resistance. Oncogene 22:7369-7375.

37. Bandyopadhyay U, Das O, Banerjee RK (1999) Reactive oxygen species: Oxidative damage and Pathogenesis. Curr Sci 77: 658-666. 
Citation: Reddy HA, Venkatappa B (2016) Effect of Staphylococcus aureus Infection on Biochemical and Antioxidant Activities of Fifth Instar Silkworm Larvae (Bombyx mori L.). J Bacteriol Parasitol 7: 286. doi:10.4172/2155-9597.1000286

Page 7 of 7

38. Pedrini N, Ortiz-Urquiza A, Huarte-Bonnet C, Zhang S, Keyhani NO (2013) Targeting of insect epicuticular lipids by the entomopathogenic fungus Beauveria bassiana: hydrocarbonoxidation within the context of a host-pathogen interaction. Front Microbiol 4: 24

39. Pedrini N, Crespo R, Juárez MP (2007) Biochemistry of insect epicuticle degradation by entomopathogenic fungi. Comp Biochem Physiol C Toxicol Pharmacol 146: 124-137.
40. Weisiger RA, Fridovich I (1973) Superoxide dismutase: organelle specificity. J Biol Chem 248: 3582-3592.

41. Dourado LA, Ribeiro LF, Brancalhão RM, Tavares J, Borges AR (2011) Silkworm salivary glands are not susceptible to Bombyx mori nuclear polyhedrosis virus. Genet Mol Res 10: 335-339. 